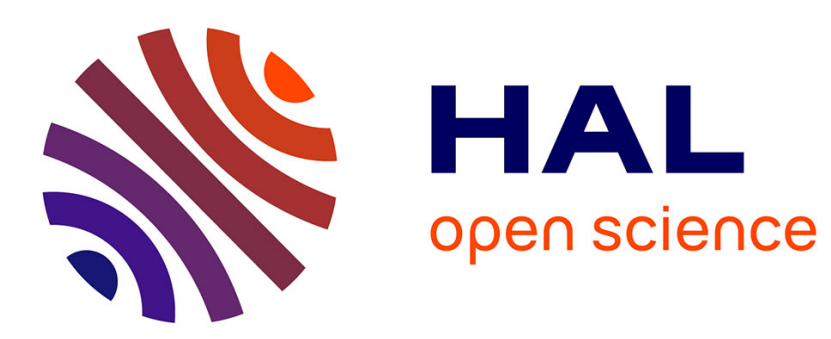

\title{
Isotopic signatures of sulfur in shallow Antarctic ice cores
}

\author{
Nicolas Patris, Robert Delmas, Jean Jouzel
}

\section{To cite this version:}

Nicolas Patris, Robert Delmas, Jean Jouzel. Isotopic signatures of sulfur in shallow Antarctic ice cores. Journal of Geophysical Research: Atmospheres, 2000, 105 (D6), pp.7071-7078. 10.1029/1999JD900974 . hal-03110214

\section{HAL Id: hal-03110214 https://hal.science/hal-03110214}

Submitted on 8 Feb 2021

HAL is a multi-disciplinary open access archive for the deposit and dissemination of scientific research documents, whether they are published or not. The documents may come from teaching and research institutions in France or abroad, or from public or private research centers.
L'archive ouverte pluridisciplinaire HAL, est destinée au dépôt et à la diffusion de documents scientifiques de niveau recherche, publiés ou non, émanant des établissements d'enseignement et de recherche français ou étrangers, des laboratoires publics ou privés. 


\title{
Isotopic signatures of sulfur in shallow Antarctic ice cores
}

\author{
Nicolas Patris \\ Laboratoire des Sciences du Climat et de l'Environnement, CEA-CNRS, Gif-sur-Yvette, France \\ Robert J. Delmas \\ Laboratoire de Glaciologie et Géophysique de l'Environnement, CNRS, St-Martin d'Hères, France \\ Jean Jouzel \\ Laboratoire des Sciences du Climat et de l'Environnement, CEA-CNRS, Gif-sur-Yvette, France
}

\begin{abstract}
Sulfur stable isotopes from Antarctic snow samples have been used to assess sources of sulfate. The novel experimental procedure presented here is suitable for the determination of sulfur isotopic composition at the micromolar level and has been adapted to polar ice samples. Measurements were carried out on three contiguous firn cores (PS6, PS7, and PS8) collected near Amundsen-Scott Station (South Pole), covering the record of the Agung eruption (March 1963). Taking into account the minimum amount of sulfate required for the isotope analysis, it has been possible to delineate three time periods along the cores: pre-1964 years (background sulfate level), 1964-1965 (volcanic deposition peak), and 1966-1968 (volcanic peak tail). A deeper part of another core (PS12) has been used to extend the background picture. Assuming the conservation of isotopic signatures during long-range transport and deposition processes, results demonstrate the significant volcanic contribution to sulfate deposition on the central Antarctic ice cap a few months after a major low-latitude eruption. They also confirm the marine biogenic origin of present background sulfate. Isotopic signatures $\left(\delta^{34} \mathrm{~S}\right)$ of marine biogenic sulfate and volcanic sulfate from Mt. Agung have been found to be $+18.6 \pm 0.9 \%$ and $+2.7 \pm 1.1 \%$, respectively.
\end{abstract}

\section{Introduction}

Stable sulfur isotopes have proven to be most helpful in sulfur biogeochemical cycle investigations. Sources of atmospheric sulfur are various and spread all over the planet. They exhibit isotopic signatures, i.e. characteristic ${ }^{34} \mathrm{~S} /{ }^{32} \mathrm{~S}$ ratios [Nielsen, 1974; Newman et al., 1991] that can be used to trace transport and/or transformation of atmospheric S-bearing compounds. The technique has been successfully employed in chemical mechanism studies [Saltzman et al., 1983; Tanaka et al., 1994], pollution tracing [Grey and Jensen, 1972; Nriagu et al., 1991; Li and Barrie, 1993; Novak et al., 1996], source assessment [Calhoun et al., 1991; McArdle and Liss, 1995; McArdle et al., 1998], geothermal processes studies [Robinson, 1987], and so forth. This technique is most successful when a limited number of isotopically discriminated contributors is assumed.

Polar ice archives are currently used to document past variations of atmospheric sulfur compounds and help elucidate their link with climate [Legrand, 1997, and references therein]. Antarctica is particularly appropriate to study the natural part of the atmospheric sulfur cycle, for its atmosphere is relatively free of anthropogenic sulfur pollution. Sulfate is the major $S$-bearing compound present in polar ice. Methane sulfonic acid (MSA) is the only other significant species and is exclusively of biogenic origin. Its concentration averages

Copyright 2000 by the American Geophysical Union.

Paper number 1999JD900974

0148-0227/00/1999JD900974\$09.00
$-10 \%$ of the total sulfate concentration [Legrand and FenietSaigne, 1991]. It is generally accepted that sulfate deposition in central Antarctica has three components [Legrand and Delmas, 1984]: (1) marine biogenic sulfate, the dominant contributor, exhibiting a clear seasonal pattern (summer maxima); (2) sea-salt sulfate, a minor contributor $(<10 \%$ of total sulfate), with a seasonal trend the inverse of that of biogenic sulfate; (3) continental sulfate (including volcanic, mineral, contınental biogenic, and anthropogenic sources), little of which reaches Antarctica under present climatic conditions. The only significant continental contributions are sporadic volcanic inputs transported through the high troposphere or low stratosphere (Junge layer) where particulate sulfate lifetime is long enough to undergo hemispheric transport [Castleman et al., 1973; Lazrus et al., 1979; Delmas et al., 1992]. Ice layers contaminated by volcanic material generally feature unusually high acidity levels, sulfate concentration enhancements, and, in some cases, tephras and fine ash particles [Hammer, 1977; De Angelis et al., 1985]. It has been observed that the amplitude of a volcanic signal in the ice at a given location depends not only on the atmospheric gaseous loading but also on the snow accumulation rate at this location [Delmas et al., 1985]. Today, Antarctic and sub-Antarctic volcanic activities are relatively low [Delmas, 1982]. Therefore volcanic signals recorded in central Antarctica are most likely linked to midlatitude or low-latitude eruptions of global concern [Delmas et al., 1985].

$S$ isotope measurement is an elegant way to identify potential sulfur sources. Antarctica seems to be particularly surtable for such studies because of the limited number of 
potential sources. However, to date, the isotopic signature of sulfur present in polar ice has not been determined, largely owing to the difficulty of performing isotope measurements on very small sulfate amounts. Sea-salt sulfate exhibits a fairly constant $S$ isotope ratio throughout open oceans, enriched in the heavier isotope ${ }^{34} \mathrm{~S}$ relative to the Cañon Diablo Troilite (CDT) reference. The $\delta^{34} S$ (as defined in equation (1)) for seasalt sulfate is $+21 \%$ o [Rees et al., 1978]. Volcanic $\delta^{34} S$ is more variable but is contained in general in the 0 to $+5 \%$ interval when averaged over large scales by atmospheric transport. The isotopic signature of marine biogenic sulfur is not well defined. The theoretical range for marine biogenic sulfate $\delta^{34} \mathrm{~S}$ lies between +14 and $+22 \%$. Isotope measurements performed on Pacific marine and North Atlantic coastal aerosols led to values covering the theoretical range $(+15.6 \pm 3.1 \%$ o [Calhoun et al., 1991] and $+22 \% \circ$ [McArdle and Liss, 1995]).

The objective of this study is to use sulfur stable isotopes to yield new insight into sources of south polar sulfate and to demonstrate the possible connection between sulfate concentration peaks in the snow and the occurrence of major volcanic events at low latitudes. It will also be an opportunity to assign a value to the isotopic signature of background atmospheric sulfur, thought to be of essentially marine biogenic origin [Legrand and Delmas, 1984].

The Agung eruption $\left(8^{\circ} \mathrm{S}, 115^{\circ} \mathrm{E}\right.$; March 1963$)$ is one of the most prominent volcanic events of the twentieth century. It has been estimated from glaciological studies that $\sim 10 \mathrm{Tg}$ of $\mathrm{S}$ were introduced into the stratosphere by this eruption [Legrand and Delmas, 1987]. The sulfuric acid veil linked to this event was detected over the South Pole as early as autumn 1963 [Dyer and Hicks, 1968]. However, the climax of sulfate deposition in south polar ice occurred $\sim 1$ year later [Legrand and Delmas, 1984]. At the South Pole the sulfate peak is well defined above the natural background variability, because of the relatively low and regular snow accumulation rate $\left(8.3 \mathrm{~g} \mathrm{~cm}^{-2} \mathrm{yr}^{-1}\right.$ [Jouzel et al., 1983]).

We present here the first $S$ isotope measurements performed on polar ice core samples, focused on the Agung signal. We developed an analytical method that allows micromolar sulfate amounts to be extracted from ice and analyzed by continuous flow mass spectrometry (CF-IRMS), using an elemental analyzer coupled to the mass spectrometer.

\section{Experimental Procedure}

\subsection{Sampling}

South Pole Station (elevation $2850 \mathrm{~m}$ above sea level) lies on the side of the Antarctic plateau, $\sim 1000 \mathrm{~km}$ from the ocean shores and ice shelves. Sampling sites were located in clean sectors, a few kilometers away from the station. Ice cores were collected during austral summer 1983-1984.

Legrand and Delmas [1984] showed that background sulfate concentration in South Pole ice follows a seasonal cycle varying between 50 and $100 \mathrm{ng} \mathrm{g}^{-1}$ and that the sulfate peak corresponding to the Agung eruption reached over $150 \mathrm{ng} \mathrm{g}^{-1}$ of $\mathrm{SO}_{4}{ }^{2-}$ along a few tens of centimeters of accumulated snow. Roughly $1 \mu \mathrm{mol}$ of sulfate $(100 \mu \mathrm{g})$ is necessary for isotope analysis. Considering the diameter of drilled cores $(-5$ to $8 \mathrm{~cm}$ of decontaminated ice), one single core would provide an insufficient quantity to describe accurately the time sequence of the event. In order to obtain enough sulfate several cores were a

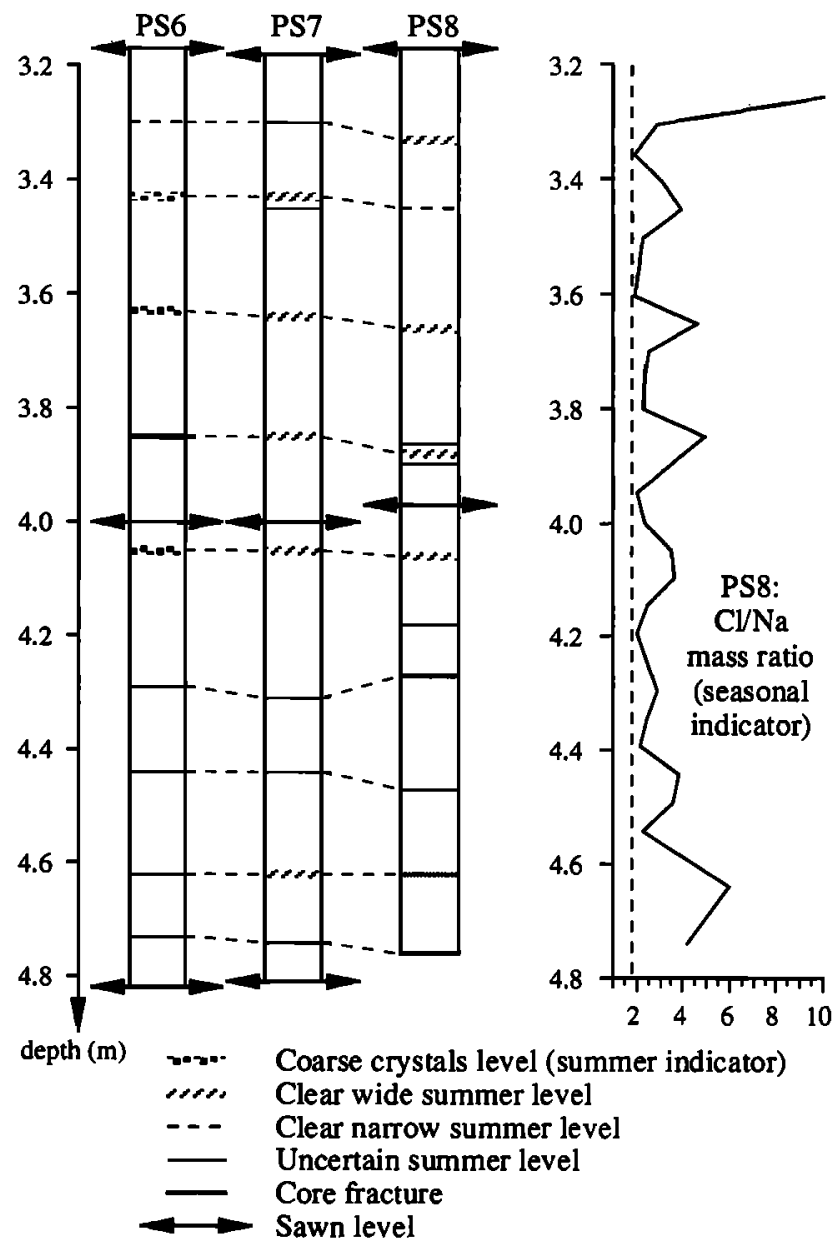

Figure 1. (a) Stratigraphy observations along PS6, PS7 and PS8; (b) Cl/Na mass ratio as measured in PS8 core, indicating winter levels as it approaches 1.8 (dashed line), representative of sea spray.

collected. Three (PS6, PS7 and PS8) were drilled contiguously to a depth of $5.20 \mathrm{~m}$. On the basis of dating estimates, the 3.20 to $4.80 \mathrm{~m}$ depth parts were stored for this study in sealed polyethylene bags at $-25^{\circ} \mathrm{C}$ until processing. Another core, representative of pre-Agung conditions (PS12, between 6.60 and $8.50 \mathrm{~m}$ deep), was drilled and preserved under the same conditions.

\subsection{Core Dating}

Visual stratigraphy observations for PS6, PS7, and PS8 (J.-R. Petit, personal communication, 1998) are shown in Figure 1. At these depths, summer strata may be visually observed with the naked eye. However, several layers are questionable. Comparison between the three cores helps in determining the seasonal intervals. We can identify nine summer levels along the three cores (dashed lines in Figure 1a). Between 3.20 and $4.80 \mathrm{~m}$ deep, the average annual interval is $\sim 18 \mathrm{~cm}$, in agreement with the $8.3 \mathrm{~g} \mathrm{~cm}^{-2} \mathrm{yr}^{-1}$ accumulation quoted earlier.

On the basis of observations in other South Pole cores the Agung event record is contained in the 1964 and 1965 layers [Legrand and Delmas, 1984]. Ion chromatography was used to 
precisely locate the volcanic signal. PS8 was subsampled in $5 \mathrm{~cm}$ sections all along the core, decontaminated, melted, and analyzed for major ions $\left(\mathrm{SO}_{4}^{2-}, \mathrm{NO}_{3}^{-}, \mathrm{Cl}^{-}, \mathrm{MSA}, \mathrm{Na}^{+}, \mathrm{Ca}^{2+}\right.$, $\mathrm{Mg}^{2+}, \mathrm{K}^{+}$, and $\mathrm{NH}_{4}^{+}$) at the $\mathrm{ng} \mathrm{g}^{-1}$ level [Legrand et al., 1984]. It was also used to check the possible chemical alteration of the ice during long (15 years) storage.

PS12 was partly dated by Feniet [1990]. Extrapolation of this dating to our core (6.6 to $8.5 \mathrm{~m}$ deep) suggests that it is contaned within the 1930-1950 layers. More precise dating was not needed for our purpose. PS12 was subsampled similarly to PS8 and analyzed for major anions only.

\subsection{Sample Processing}

Because of the very low quantities of sulfur handled in this study, we gave specific attention to contamination prevention and yield optimization. All steps of the procedure were checked for possible sulfur contamination and sulfur isotope fractionation. All vessels and tools were cleaned following stringent procedures, including ultrasonic washing of glassware in ultrapure water $(18.2 \mathrm{M} \Omega)$. At each critical step of the treatment, samples were protected from particulate contamination in clean laminar flows (class 100) and from possible gas contamination using controlled atmosphere above melted samples, as described below.

Firn cores were decontaminated with the help of a plane mounted on a stainless steel bench under a clean laminar aurflow in a $-15^{\circ} \mathrm{C}$ room. Two outer centimeters of the core were removed. Clean core was then kept frozen in sealed polyethylene bags rinsed with ultrapure water, until further processing.

Thereafter, decontaminated core samples were allowed to melt overnight at ambient temperature in glass containers sealed in airtight polyethylene bags. Meltwater was weighed and gently evaporated under partial vacuum and moderate heating in a rotary evaporator. The procedure has been optımized to avoid any gaseous contamination or sulfate loss due to intense evaporation or explosive boiling. Starting volumes ranged from $1 \mathrm{~L}$ up to $2.5 \mathrm{~L}$ of meltwater, depending on initial sulfate concentration in the ice. Evaporation was continued until sample volume was reduced down to between 10 and $20 \mathrm{~mL}$. Liquid concentrate was then further evaporated in a pure argon stream under gentle heating. The last $2 \mathrm{~mL}$ were taken up with a polypropylene syringe free of sulfur contamination.

The final evaporation step was conducted under pure argon. Sample was introduced drop by drop into a heated tin capsule containing $\sim 1$ to $1.5 \mathrm{mg}$ of acid-washed Chromosorb ${ }^{\mathrm{TM}}$ resin. Water evaporated as sulfate precipitated in the capsule. The tin foil was then wrapped up and compacted, ready to be put in the elemental analyzer. For a $2 \mathrm{~kg}$ decontaminated ice sample, $\sim 6$ hours were necessary for each of the three evaporation steps.

\subsection{Continuous Flow Mass Spectrometry}

Tin-encapsulated samples were flash combusted in a pulse of oxygen at a temperature locally reaching $1800^{\circ} \mathrm{C}$. Sulfur oxidation products were $\mathrm{SO}_{2}$ and $\mathrm{SO}_{3}$. Evolved gases (mainly $\mathrm{N}_{2}, \mathrm{CO}_{2}, \mathrm{H}_{2} \mathrm{O}, \mathrm{SO}_{2}$, and $\mathrm{SO}_{3}$ ) were carried by pure helium through hot reduced copper where $\mathrm{SO}_{3}$ was reduced to $\mathrm{SO}_{2}$, then through a desiccating trap, and separated chromatographically in a $0.8 \mathrm{~m}$ long Porapak $\mathrm{S}$ column at $80^{\circ} \mathrm{C}$. Nitrogen and carbon dioxide were expelled out of the gas chromatograph in
$<1 \mathrm{~min}$ after combustion. Sulfur dioxide detection started after $1 \mathrm{~min} 20 \mathrm{~s}$. $\mathrm{SO}_{2}$ was introduced into the source of the mass spectrometer through a split interface via a silica capillary [Giesemann et al., 1994].

Isotopic composition of the samples is compared to that of international standards from the International Atomic Energy Agency and the National Bureau of Standards (IAEA-S1, IAEA-S2 and NBS-127). The usual delta notation is used for 1sotopic results:

$$
\delta^{34} S(\% o)=\left\{\frac{\left({ }^{34} S /{ }^{32} S\right)_{\text {sample }}}{\left({ }^{34} S /{ }^{32} S\right)_{\text {reference }}}-1\right\} \times 1000 .
$$

Isotopic results are presented in the Vienna-CDT (VCDT) scale, where the international standard IAEA-S1 (silver sulfide formerly called NZ1) has the value $\delta^{34} \mathrm{~S}=-0.3 \%$ VCDT [Robinson, 1995]. Oxygen used for sample combustion is homogenous and in large excess. The influence of oxygen isotopes on $\mathrm{S}$ isotopic measurements of $\mathrm{SO}_{2}$ is therefore expected to be reproducible. The combustion of standards of known $\delta^{34} \mathrm{~S}$ composition is used to perform the calibration between measured $\delta^{66}\left(\mathrm{SO}_{2}\right)$ and corrected $\delta^{34} \mathrm{~S}$. Overall experimental uncertainty for nonrepeatable measurements lies under $\pm 0.5 \%$ o $(1 \sigma)$.

The whole procedure (sulfate extraction and isotope analysis) was tested by the use of dilute standard solutions which have been processed the same way as the samples. Means and dispersions of the isotopic measurements were comparable for concentrated solutions and direct standard combustion. The elemental analyzer used for combustion and purification is a Carlo Erba NC-2500; isotope measurements were carried out on a Finnigan MAT-252 mass spectrometer.

\section{Results and Discussion}

\subsection{PS8 and PS12 Ion Chromatography Analysis}

Ion analyses of PS8 and PS12 are presented in Figure 2, and averaged values are summarized in Table 1 . In general, values are consistent with previous studies based on other cores from the South Pole area [Legrand and Delmas, 1984; Kirchner, 1988]. This suggests that no alteration of the cores occurred over the 15 years of frozen storage.

3.1.1. Non-S-bearing compounds. Strong seasonal patterns of $\mathrm{Na}^{+}$and $\mathrm{Cl}^{-}$concentrations (Figure 2b) are used to validate stratification observations. Both ions show maxima in winter and minima in summer. The $\mathrm{Cl} / \mathrm{Na}^{+}$mass ratio profile reaches winter minima very close to the oceanic value of 1.8 (Figure 2c), which is consistent with a lack of chemical fractionation of sea-salt in winter [Legrand and Delmas, 1988]. The $\mathrm{Cl} / \mathrm{Na}^{+}$profile is also displayed Figure $1 \mathrm{~b}$ along with stratigraphy, so that agreement between this seasonal marker and observed stratification can be checked. Chloride concentration reaches one higher winter maximum in the shallowest part of the core $\left(75 \mathrm{ng} \mathrm{g}^{-1},-3.50 \mathrm{~m}\right.$ ). This chemical feature can also be noticed in previous studies of South Pole ice, where it corresponds to the 1966 winter layer [Legrand and Delmas, 1984] and thus can be used as an accurate marker.

Nitrate concentration variability is as expected in south polar ice (ranging from 70 to $120 \mathrm{ng} \mathrm{g}^{-1}$, Figure 2a) but does not match the regular seasonal pattern observed for $\mathrm{Cl}^{-}$and $\mathrm{Na}^{+}$. This observation is probably due to postdepositional artifacts [Wagnon et al., 1999]. 


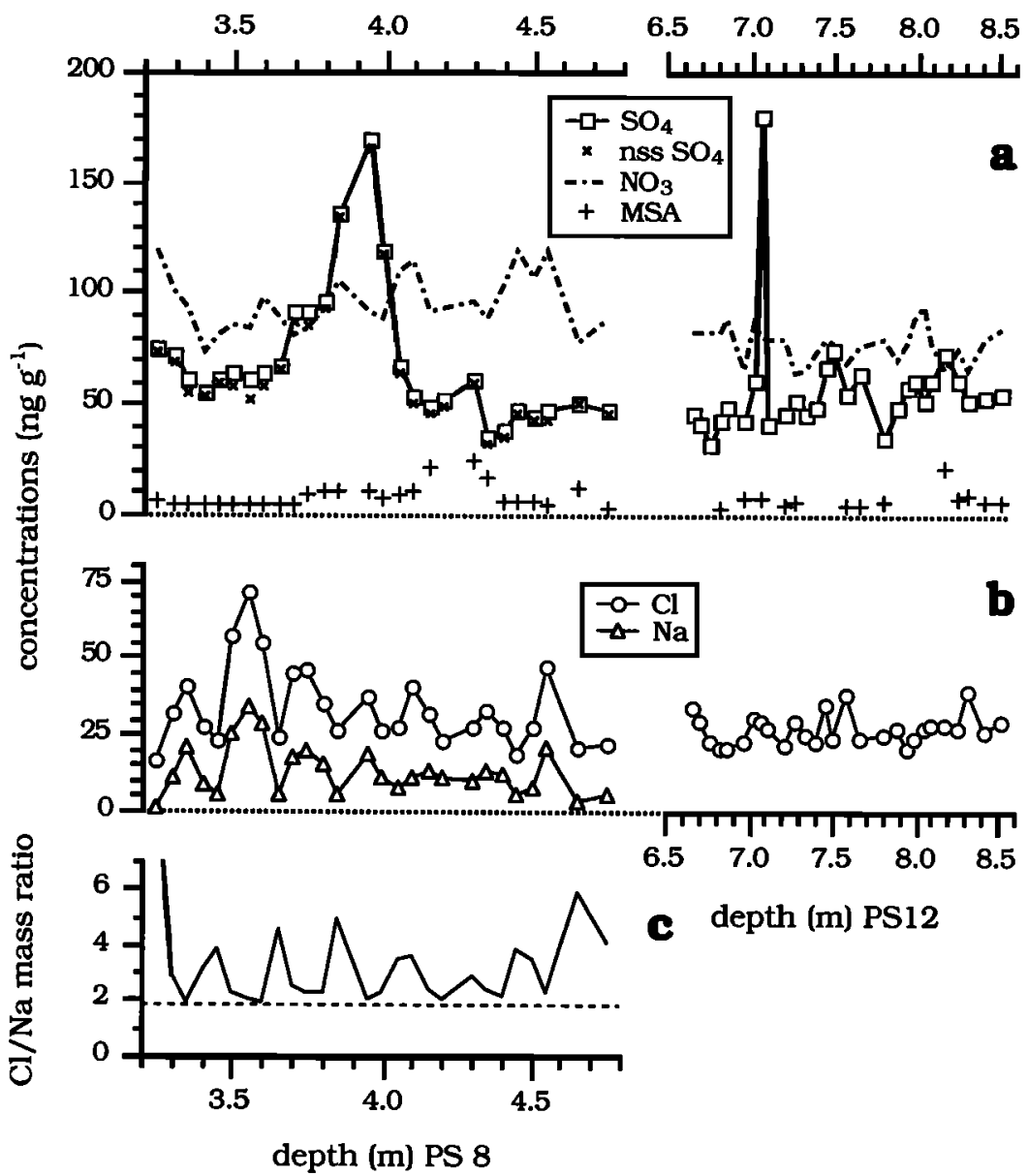

Figure 2. Ion profiles for (left) PS8 and (right) PS12 (anions only) cores: (a) sulfate (total and non-sea-salt sulfate), methane sulfonic acid, and nitrate profiles; (b) chloride and sodium profiles; (c) $\mathrm{Cl} / \mathrm{Na}$ mass ratio for PS8. (Note that PS8 and PS12 depth scales are not equal.)

Minor ion levels (cations, Table 1) are in the expected range too, showing no noticeable chemical contamination of the core. Means and variabilities of chloride and nitrate along PS12 are in good agreement with PS8 background values.

3.1.2. Sulfur species. The non-sea-salt sulfate concentration $\left[\mathrm{nss} \mathrm{SO}_{4}\right]$ was calculated from $\left[\mathrm{SO}_{4}{ }^{2-}\right]$ and $\left[\mathrm{Na}^{+}\right]$data by the following equation:

$$
\begin{aligned}
& {\left[\mathrm{nss} \mathrm{SO}_{4}^{2-}\right]=\left[\mathrm{SO}_{4}^{2-}\right]_{\mathrm{tot}}-\left[\mathrm{ss} \mathrm{SO}_{4}^{2-}\right]} \\
& =\left[\mathrm{SO}_{4}^{2-}\right]_{\text {tot }}-\left\{\left[\mathrm{Na}^{+}\right]\left(\frac{\mathrm{SO}_{4}^{2-}}{\mathrm{Na}^{+}}\right)_{\text {seawater }}\right\} \text {, }
\end{aligned}
$$

where [ss $\left.\mathrm{SO}_{4}{ }^{2-}\right]$ is the sea-salt component of the deposited sulfate, estimated using the mass ratio defined as follows:

$$
\left(\mathrm{ss} \mathrm{SO}_{4}^{2-} / \mathrm{Na}^{+}\right)_{1 \mathrm{ce}} \cong\left(\mathrm{SO}_{4}^{2-} / \mathrm{Na}^{+}\right)_{\text {seawaler }}=0.25 \text {. }
$$

Sea-salt sulfate represents a minor part of sulfate deposited in South Pole ice (between $<1$ and $10 \%$ of total $\mathrm{SO}_{4}$, Figure 2a). Background concentrations of nss sulfate (i.e., deeper than $4.10 \mathrm{~m}$, including PS12) range between 30 and $75 \mathrm{ng} \mathrm{g}^{-1}$. The Agung sulfate peak, obvious in the PS8 [SO ${ }_{4}^{2-}$ ] profile, can be found between 4.10 and $3.65 \mathrm{~m}$ depths. [ $\mathrm{SO}_{4}{ }^{2-}$ ] reaches $170 \mathrm{ng} \mathrm{g}^{-1}$, which is nearly 4 times the background

Table 1. Averaged Ion Concentrations for the Three PS8 Sections (Between 3.25 and $4.70 \mathrm{~m}$ ) and the PS12 Section (Between 6.60 and $8.50 \mathrm{~m}$ )

\begin{tabular}{lccccccccc}
\hline \multirow{2}{*}{ Depths, m } & \multicolumn{7}{c}{ Concentrations, $\mathrm{ng} \mathrm{g}^{-1}$} \\
\cline { 2 - 9 } & $\mathrm{MSA}$ & $\mathrm{Cl}$ & $\mathrm{NO}_{3}{ }^{-}$ & $\mathrm{SO}_{4}{ }^{2-}$ & $\mathrm{Na}^{+}$ & $\mathrm{NH}_{4}^{+}$ & $\mathrm{K}^{+}$ & $\mathrm{Mg}^{2+}$ & $\mathrm{Ca}^{2+}$ \\
\hline $3.25-3.65$ & $5.1 \pm 0.6$ & $38.4 \pm 18.7$ & $91.4 \pm 13.5$ & $64.6 \pm 5.8$ & $15.6 \pm 11.6$ & $2.2 \pm 0.8$ & $3.0 \pm 2.2$ & $1.8 \pm 1.3$ & $3.8 \pm 3.0$ \\
$3.65-405$ & $91 \pm 2.4$ & $34.7 \pm 86$ & $93.2 \pm 10.9$ & $117.4 \pm 30.9$ & $13.7 \pm 5.6$ & $1.8 \pm 0.4$ & $1.3 \pm 0.4$ & $1.4 \pm 0.5$ & $2.6 \pm 0.6$ \\
$4.05-4.70$ & $11.4 \pm 7.4$ & $290 \pm 8.6$ & $100.0 \pm 14.0$ & $49.3 \pm 8.8$ & $10.2 \pm 4.9$ & $1.6 \pm 1.1$ & $2.1 \pm 17$ & $1.1 \pm 0.6$ & $2.4 \pm 2.3$ \\
$6.60-850$ & $73 \pm 4.4$ & $27.3 \pm 4.9$ & $77.6 \pm 7.9$ & $524 \pm 10.7$ & & & & & \\
\hline
\end{tabular}


concentration. The sulfate profile does not return to the preAgung background level before the shallower limit of our sampling.

The MSA concentration is also at expected levels: from 4 to $12 \mathrm{ng} \mathrm{g}^{-1}$. One can also distinguish a $25 \mathrm{ng} \mathrm{g}^{-1}$ peak 1 year before Agung deposition [Legrand and Feniet-Saigne, 1991]. Dating based on the remarkable $\left[\mathrm{Cl}^{-}\right]$and [MSA] spikes mentioned and on the sulfate profile allows undeniable assignment of the years spanned: PS8 covers the period from 1960 to early 1968.

PS12 sulfate profile exhibits a clear narrow peak at $7.05 \mathrm{~m}$ depth (around 1942 A.D.). Cation analysis performed on this subsample indicates an acidic, probably volcanic, layer. There is no known significant volcanic horizon at this period of time [Legrand and Delmas, 1987]. The sharpness of the peak suggests a tropospheric volcanic load of limited strength. PS12 being dedicated to background sulfate measurement, the suspected layer has been removed before melting to ensure the representativeness of the sample.

\subsection{Isotope Results and Discussion}

As mentioned earlier, $1 \mu \mathrm{mol}$ of sulfate is required for reliable sample handling and isotope measurements. Sample partition is based on ion analysis. Considering that $\sim 100 \mathrm{~g}$ of useful decontaminated firn are available from each $10 \mathrm{~cm}$ long piece of core, PS6, PS7 and PS8 were split into three parts. Corresponding parts from the three cores were melted together. PS12 represents one additional sample. Results are shown in Table 2.

The measured isotopic composition of a sample can be decomposed into three terms representative of each contributor:

$$
\delta_{\text {mes }}=f_{\mathrm{ss}} \delta_{\mathrm{ss}}+f_{\mathrm{mb}} \delta_{\mathrm{mb}}+f_{\mathrm{v}} \delta_{\mathrm{v}}=f_{\mathrm{ss}} \delta_{\mathrm{ss}}+f_{\mathrm{nss}} \delta_{\mathrm{mss}},
$$

where $\delta_{\text {mes }}$ stands for measured $\delta^{34} \mathrm{~S} ; \delta_{\mathrm{ss}}, \delta_{\mathrm{mb}}$, and $\delta_{\mathrm{v}}$ stand for the isotopic signatures of the sea-salt, marine biogenic, and volcanic components, respectively; $f_{\mathrm{ss}}, f_{\mathrm{mb}}$, and $f_{\mathrm{v}}$ stand for the mass fractions of the components in the same order; and $f_{\text {nss }}$ and $\delta_{\text {nss }}$ refer to overall non-sea-salt contribution mass fraction and isotopic signature. Such a decomposition will be used below for the interpretation of the data.

3.2.1. Recent background level. Estimates based on the ionic composition of the ice suggested that during nonvolcanic periods, marine biogenic sulfate represents the major part of sulfate ice content in central Antarctica, whereas background volcanic sulfate and sea-salt sulfate each account for approximately half of the remaining sulfate content [Legrand and Delmas, 1984].

Table 2. Sulfur Isotopic Composition of the Ice Samples

\begin{tabular}{lccc}
\hline Depths, m & $\begin{array}{c}\text { Average }\left[\mathrm{SO}_{4}\right]_{\mathrm{\omega l}}, \\
\mathrm{ng} \mathrm{g}^{-1}\end{array}$ & $\begin{array}{c}\text { Mass of Ice, } \\
\mathbf{~ k g}\end{array}$ & $\begin{array}{l}\delta^{34} \mathrm{~S}, \\
\% \circ\end{array}$ \\
\hline $3.25-3.65^{\mathrm{a}}$ & 65 & 1.5 & +14.8 \\
$3.65-4.05^{\text {a }}$ & 110 & 1.0 & +9.3 \\
$4.05-4.70^{\mathrm{a}}$ & 48 & 2.1 & +18.1 \\
$6.60-8.50^{\mathrm{b}}$ & 52 & 2.5 & +17.7 \\
\hline
\end{tabular}

Values of $\delta^{34} S$ are $\pm 0.5 \%$.

"PS6, PS7, and PS8 sections, corresponding to PS8 depths according to stratigraphy (Figure 1a).

${ }^{b}$ PS12 section.
Table 3. Estimated Apportionment of Firn Sulfate Amongst Its Three Main Components (Sea-Salt, Marine Biogenic, and Volcanic $\mathrm{SO}_{4}$ )

\begin{tabular}{|c|c|c|}
\hline Contributors ${ }^{a}$ & $\begin{array}{l}\text { Average Contribution, } \\
\text { ng g }^{-1}\end{array}$ & $\begin{array}{c}\delta^{34} S \text { Range, } \\
\% o\end{array}$ \\
\hline \multicolumn{3}{|c|}{ PS6-PS7-PS8 $(4.05-4.80 \mathrm{~m})+P S 12(6.60-8.50 \mathrm{~m})$} \\
\hline Total $\mathrm{SO}_{4}$ (measured) & 50 & $+18.0( \pm 0.5)$ \\
\hline $\begin{array}{l}\text { Sea-salt } \mathrm{SO}_{4} \\
\text { Volcanic } \mathrm{SO}_{4} \\
\text { Marine biogenic } \mathrm{SO}_{4}\end{array}$ & $\begin{array}{c}3 \\
0-4 \\
43-47\end{array}$ & $\begin{array}{c}+21 \\
0 \text { to }+5 \\
?(+15 \text { to }+22)\end{array}$ \\
\hline \multicolumn{3}{|c|}{ PS6-PS7-PS8 $(3.65-4.05 \mathrm{~m})$} \\
\hline Total $\mathrm{SO}_{4}$ (measured) & 117 & $+9.3( \pm 0.5)$ \\
\hline $\begin{array}{l}\text { Sea-salt } \mathrm{SO}_{4} \\
\text { Marine biogenic } \mathrm{SO}_{4} \\
\text { Volcanic } \mathrm{SO}_{4}\end{array}$ & $\begin{array}{c}3 \\
43-47 \\
67-71\end{array}$ & $\begin{array}{c}+21 \\
+18.6( \pm 0.9) d \\
?(0 \text { to }+5)\end{array}$ \\
\hline \multicolumn{3}{|c|}{ PS6-PS7-PS8 $(3.20-3.65 \mathrm{~m})$} \\
\hline Total $\mathrm{SO}_{4}$ (measured) & 65 & $+14.8( \pm 0.5)$ \\
\hline $\begin{array}{l}\text { Sea-salt } \mathrm{SO}_{4} \\
\text { Marine biogenic } \mathrm{SO}_{4} \\
\text { Volcanic } \mathrm{SO}_{4}\end{array}$ & $\begin{array}{c}4 \\
43-47 \\
14-18\end{array}$ & $\begin{array}{c}+21 \\
+18.6( \pm 0.9)^{d} \\
+2.7( \pm 1.1)^{d}\end{array}$ \\
\hline
\end{tabular}

"Contributors to total sulfate deposited in south polar snow.

${ }^{b}$ A veraged measured total sulfate concentration and contributions estimated from chemical studies [Legrand and Delmas, 1984; this work].

${ }^{-}$Measured $\delta^{34} S$ (compare Table 2) and $\delta^{34} S$ ranges for each contributor, as taken from literature [Rees et al., 1978; Calhoun et al, 1991; Nielsen et al., 1991; McArdle and Liss, 1995] or deduced from present calculations (marked "d").

'Deduced from present calculations (see text for details).

Background conditions in south polar ice are represented by the two samples: PS6-PS7-PS8 below $4.05 \mathrm{~m}$ and PS12. Averaged measurements are displayed in the upper third of Table 3, where the three contributors to background sulfate are presented together with estimates of their isotopic signatures taken from literature. Sea-salt contribution is most precisely

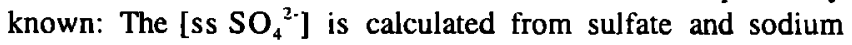
concentrations (see section 3.1), and isotopic composition is well defined at $+21.0 \%$ [Rees et al., 1978]. We can therefore retrieve the non-sea-salt sulfate component: [nss $\mathrm{SO}_{4}{ }^{2-}$ ] = $47 \mathrm{ng} \mathrm{g}^{-1}$, and $f_{\mathrm{nss}} \delta_{\mathrm{nss}}=f_{\mathrm{mb}} \delta_{\mathrm{mb}}+f_{\mathrm{v}} \delta_{\mathrm{v}}=+16.7 \pm 0.5 \%$ (with $f_{\text {nss }}=$ $f_{\mathrm{mb}}+f_{\mathrm{v}}=47 / 50$ ), which leads to $\delta^{34} \mathrm{~S}_{\mathrm{nss}}=+17.8 \% \circ \pm 0.5 \%$ o. This precludes any lower value for marine biogenic sulfate signature at this site.

Volcanic background inputs are considered to be quite small during undisturbed periods. If we assume that $f_{v}$ represents between 0 and $8 \%$ of total sulfate [Legrand and Delmas, 1984] and that $\delta_{v}$ is confined to the range 0 to $+5 \%$ [Nielsen et al., 1991], we can define the marine biogenic signature as follows:

$$
\delta_{\mathrm{mb}}=\frac{1}{f_{\mathrm{mb}}}\left(16.7-f_{\mathrm{v}} \delta_{\mathrm{v}}\right) \quad f_{\mathrm{mb}}+f_{\mathrm{v}}=47 / 50
$$

In this simple calculation, $\delta_{\mathrm{mb}}$ varies between $+17.8 \%$ (for $f_{\mathrm{v}}=0$ ) and $+19.5 \%$ (for $\delta_{\mathrm{v}}=0 \%$ and $f_{\mathrm{v}}=8 \%$, which is an overestimate). The estimated isotopic signature for marine biogenic sulfate deposited at the South Pole is therefore $\delta_{\mathrm{mb}}=$ $+18.6 \%$ $\pm 0.9 \%$. (Uncertainty is calculated by the error propagation method.)

The present analytical procedure does not make distinctions between sulfate and MSA, as far as we know: The final dried sample should contain sulfate as well as methane sulfonic acid, 
the recovery of which has not yet been tested accurately. The measured isotopic ratio should therefore reflect total sulfur. Still, the marine biogenic contribution $\left(\mathrm{SO}_{4}+\mathrm{MSA}\right)$ will be referred to as "marine biogenic sulfate" for two reasons: (1) MSA does not represent, on average, $>10 \%$ of the total S in south polar ice. (2) Its isotopic composition should not be considerably different from that of marine biogenic sulfate [Calhoun et al., 1991]. Therefore its influence on the result should be contained within the analytical uncertainty of $\pm 0.5 \%$.

3.2.2. Volcanic peak. Assuming that marine biogenic and sea-salt sulfate depositions at the South Pole have not been noticeably altered by the volcanic event, the totality of sulfate above background level may be of volcanic origin. The three contributions for the 3.65 to $4.05 \mathrm{~m}$ deep layers are summarized in the middle third of Table 3.

A calculation similar to the one applied to background sulfate allows the definition of overall non-sea-salt signature $\delta_{\mathrm{nsn}}=+9.0 \pm 0.5 \%$. Using $\delta_{\mathrm{mb}}$ of $+18.6 \pm 0.9 \%$ yields a volcanic signature of $\delta_{v}=+2.7 \pm 1.1 \%$, which is contained within the range suggested by Nielsen et al. [1991] of 0 to $+5 \%$.

3.2.3. Volcanic peak tail. Applying the assumption of constant nonvolcanic deposition to the upper part of the core (3.25-3.65 m, lower third of Table 3 ) yields a theoretical $\delta^{34} \mathrm{~S}_{\mathrm{cak}}=f_{\mathrm{ss}} \delta_{\mathrm{ss}}+f_{\mathrm{mb}} \delta_{\mathrm{mb}}+f_{\mathrm{v}} \delta_{\mathrm{v}}$ value from Table 3 , lower third, taking into account the estimated isotopic signatures and their uncertainties. It holds, for $f_{\mathrm{mb}}=43 / 65$ and $f_{\mathrm{v}}=18 / 65$, that $\delta^{34} S_{\text {calc }}=+14.3 \pm 0.7 \%$, and for $f_{\mathrm{mh}}=47 / 65$ and $f_{\mathrm{v}}=14 / 65$, that $\delta^{34} S_{\text {calc }}=+15.3 \pm 0.7 \%$, which is in remarkable agreement with the actual measured value $\left(\delta_{\text {mes }}=+14.8 \pm 0.5 \%\right.$ ) .

Delmas et al. [1985] already suspected a volcanic origin for the "extra sulfate" above pre-Agung background level, found in the 1966 to 1969 layers. The local or hemisphenc origin of this volcanic contribution was not clear and still cannot be determined from isotopic measurements. However, support for the volcanic origin of this input is given here. Several southern or equatorial eruptions occurred during this period and are possible candidates [Newhall and Self, 1982].

3.2.4. Discussion. Figure 3 shows isotope measurements plotted against the inverse of total sulfate concentration for each sample. The linear figure obtained suggests a system combining two isotopically distinguishable contributors, one of them remaining quantitatively constant. The constant contribution is considered to be the sum of the marine (sea-salt and biogenic) sources, which are assumed not to have been altered by the volcanic input. The regression line on Figure 3 intersects the ordinate axis at the value corresponding to the isotopic signature of the varying member. The signature found is $\delta^{34} \mathrm{~S}=+2.8 \pm 0.9 \%$, which supports the hypothesis of sulfate deposition being the sum of a constant nonvolcanic source over which a volcanic perturbation is superimposed.

Direct isetope measurements of sulfur emitted by the Agung eruption were performed by Castleman et al. [1973, 1974] in stratospheric aerosols. Results revealed isotopic ratios drifting strongly over time. Starting around $+5 \%$ prior to the eruption (March 1963), $\delta^{34} \mathrm{~S}$ of stratospheric particulate sulfate shifted toward heavier values, peaking in summer 1963 $(+11.6 \%$ at $15.2 \mathrm{~km}$ altitude and $+15.8 \%$ at $18.3 \mathrm{~km}$ altitude, in the Southern Hemisphere) and then drifting substantially toward lower values. The minimum was reached in April $1965(-8.7 \%$ at $15.2 \mathrm{~km}$ altitude and below $-20 \%$ at $18.3 \mathrm{~km}$ ). This behavior revealed fractionation processes

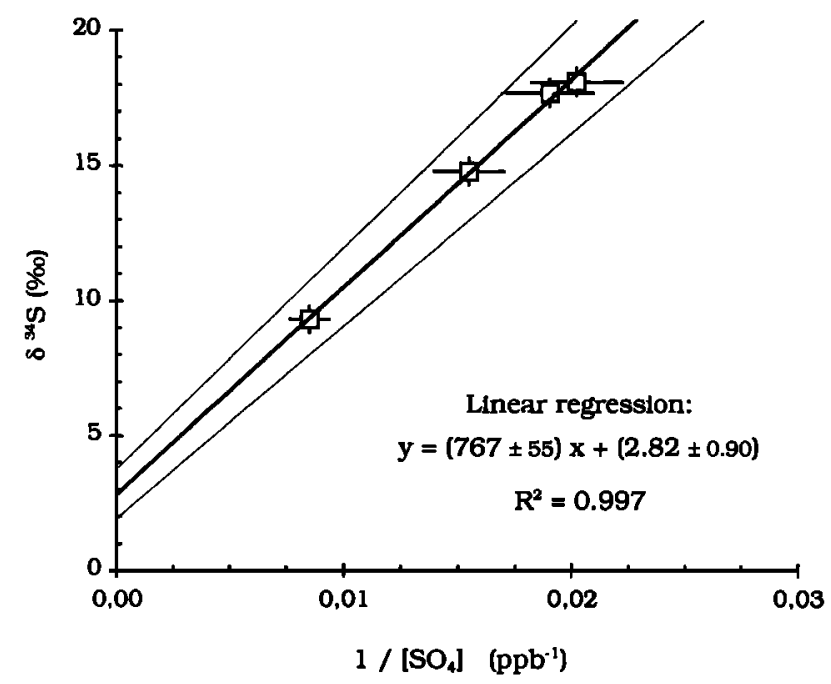

Figure 3. Measured isotopic composition as a function of the inverse of the total sulfate concentration, suggesting that the sulfate contributor bringing variability to sulfate deposition has the isotopic signature $\delta^{34} \mathrm{~S}=+2.8 \pm 0.9 \%$. (Uncertainty estimated by least squares method.)

induced by progressive action of transport, chemistry, and sulfate particle removal [Castleman et al., 1974]. Sedimentation of tephras started readily after their injection into the stratosphere. Gaseous sulfur $\left(\mathrm{SO}_{2}\right)$ underwent relatively fast horizontal homogenization and slow gas-particle conversion, explaining the time lag observed between the eruption occurrence and the maximum sulfate particle loading [Mossop, 1964]. The first sulfate aerosols being formed in the stratosphere were enriched in ${ }^{34} \mathrm{~S}$ compared to the initial gaseous load, indicating that oxidation of the heavier $S$ isotope was favored by the complex stratospheric processes. Thereafter, as its concentration diminished, $\mathrm{SO}_{2}$ became isotopically lighter, as did newly formed sulfate aerosols [Castleman et al., 1974].

Volcanic $\mathrm{SO}_{4}$ started to be deposited in polar ice by the beginning of 1964, after horizontal mixing on a large scale. Most of the deposited sulfate may therefore result from stratospheric gas-particle conversion. However, the whole signal ( 2 years of accumulation) has been used for our volcanic layer measurement. The isotopic fractionation due to stratospheric processing should then be considered to be averaged to zero in this sample. We can therefore estimate that our so-called volcanic contributor is representative of the bulk volcanic gaseous emission. Isotopic measurements on thinner ice layers (a few centimeters deep) along the Agung signal may be suggested to test the stratospheric processes described above.

Castleman et al. [1973, 1974] quoted a $\delta^{34} S$ value for background stratospheric sulfate equal to $+2.6 \pm 0.3 \%$, which happens to be very close to the volcanic signature found in the present study. Such an agreement may be quite coincidental but still deserves consideration.

\section{Conclusion}

A procedure for the determmation of isotopic composition of sulfur at the micromolar level has been successfully adapted to polar ice samples. This procedure has been used to 
confirm the assessment of sulfur sources in recent south polar snow, as deduced from glaciochemical studies. Major results may be highlighted from our preliminary measurements: (1) confirmation of the marine biogenic origin of non-seasalt sulfate at the South Pole and of the weakness of the volcanic source during background conditions; (2) definition of the sulfur isotopic signature of marine biogenic sulfate present in recent south polar snow, $8^{34} \mathrm{~S}_{\mathrm{mb}}=+18.6 \pm 0.9 \%$; (3) definition of the sulfur 1sotopic signature of Agung sulfate input to the South Pole, $\delta^{34} \mathrm{~S}_{v}=+2.7 \pm 1.1 \%$, which suggests eventual conservation of this signature throughout long-range stratospheric transport; (4) new support for the volcanic nature of the extra sulfate deposited during a few years after the Agung signal.

The fine agreement between isotopic measurements and ion analyses shows that the isotopic composition of sulfur remains a powerful source marker, even after hemispheric and high-altitude transport and transformations. No isotopically fractionating postdeposition process can be suspected at this point. Isotopic signatures obtained for major natural contributors can be used as references in future studies of the sulfur cycle on a global scale.

Isotopic measurements on thinner ice layers (a few centimeters deep) along the Agung signal are suggested to test the stratospheric processes described by Castleman et al. [1973]. Sulfur isotopes should be used in the future to study volcanic sulfate deposited in polar ice (in Antarctica, Greenland, or both for a few global events), in relation to in situ studies of volcanic material. This could provide valuable information about the fate of volcanic sulfur during its atmospheric transport, the stratospheric $S$ chemistry, and the climatic impact of explosive volcanism.

Acknowledgments. Firn cores were collected at Amundsen-Scott Station (South Pole) by M. Legrand, and J.-R. Petit. We would like to thank M. De Angelis, M. Legrand and J.-R. Pettt for their help in sample processing and helpful scientific discussions. We acknowledge the contribution of J.-J Poupeau and M. Stievenard to this work and the kind advice of A.-L. Norman for improving mass spectrometry. This research was initiated with the financial support of Commission of the European Community (Eurocore-Follow Up project STEP 90-0064) and the participation of G. Gravenhorst, H. Nielsen, J. Calhoun, and M. Rotaru. LSCE contribution $\mathrm{N}^{\circ} 324$.

\section{References}

Calhoun, J.A., T.S. Bates, and R.J. Charlson, Sulfur isotope measurements of submicrometer sulfate aerosol particles over the Pacific ocean, Geophys. Res. Lett., 18, 1877-1880, 1991.

Castleman, A.W., Jr., H.R. Munkelwitz, and B. Manowitz, Contribution of volcanic sulphur compounds to the stratospheric aerosol layer, Nature, 244, 345-346, 1973.

Castleman, A.W., Jr., H.R. Munkelwitz, and B. Manowitz, Isotopic studies of the sulfur component of the stratospheric aerosol layer, Tellus, 26, 222-234, 1974.

De Angelis, M., L. Fehrenbach, C. Jehanno, and M. Maurette, Micrometre-sized volcanic glasses in polar ices and snows, Nature, $317,52-54,1985$.

Delmas, R.J., Antarcic sulphate budget, Nature, 299, 677-678, 1982.

Delmas, R.J., M. Legrand, A.J. Aristarain, and F. Zanolini, Volcanic deposits in Antarctic snow and ice, J. Geophys. Res., 90, 12,901$12,920,1985$.

Delmas, R.J., S. Kurchner, J.M. Palais, and J.R. Petit, 1000 years of explosive volcanism recorded at the South Pole, Tellus, Ser. B, 44, 335-350, 1992.

Dyer, A.J., and B.B. Hicks, Global spread of volcanic dust from the Bali eruption of 1963, Q. J. R. Meteorol. Soc., 94, 545-554, 1968.

Feniet, C., L'acide méthanesulfonique dans la précipitation antarctique, implications pour le cycle du soufre aux hautes lattudes, Ph.D. thesis, 262 pp., Univ. Joseph Fourier - Grenoble I, Grenoble, France, 1990.

Giesemann, A., H.J. Jäger, A.L. Norman, H.R. Krouse, and W.A. Brand, On-line sulfur isotope determination using an elemental analyzer coupled to a mass spectrometer, Anal Chem., 66, 2816$2819,1994$.

Grey, D.C., and M.L. Jensen, Bacteriogenic sulfur in air pollution, Science, 177, 1099-1100, 1972.

Hammer, C.U., Past volcanism revealed by Greenland ice sheet impurities, Nature, 270, 482-486, 1977.

Jouzel, J., L. Merlivat, J.R. Petit, and C.J. Lorius, Climatic information over the last century deduced from a detailed isotopic record in the South Pole snow, J. Geophys. Res., 88, 2693-2703, 1983.

Kirchner, S., Chimie de la neige $\left(\mathrm{Na}, \mathrm{Cl}, \mathrm{NO}_{3}, \mathrm{SO}_{4}\right)$ à la station Pôle Sud, Ph.D. thesis, 260 pp., Université Paris VII, Paris, 1988.

Lazrus, A.L., R.D. Cadle, B.W. Gandrud, J.P. Greenberg, B.J. Huebert, and W.I. Rose $\mathbf{J}_{\mathbf{r}}$., Sulfur and halogen chemistry of the stratosphere and of volcanic eruption plumes, J. Geophys. Res. 84, 7869-7875, 1979.

Legrand, M., Ice-core records of atmospheric sulphur, Philos.Trans. R.Soc London, Ser. B, 352, 241-250, 1997.

Legrand, M., and R.J. Delmas, The ionic balance of Antarctic snow: A 10-year detailed record, Atmos. Environ., 18, 1867-1874, 1984.

Legrand, M., and R.J. Delmas, A 220-year continuous record of volcanic $\mathrm{H}_{2} \mathrm{SO}_{4}$ in the Antarctic ice sheet, Nature, 327, 671-676, 1987.

Legrand, M., and R.J. Delmas, Formation of $\mathrm{HCl}$ in the Antarctic atmosphere, J. Geophys. Res., 93, 7153-7168, 1988.

Legrand, M., and C. Feniet-Saigne, Methane sulfonic acid in south polar snow layers: A record of strong El Niño?, Geophys Res. Lett., 18, 187-190, 1991 .

Legrand, M., M. De Angelis, and R.J. Delmas, Ion chromatographic determination of common ions at ultratrace levels in Antarctic snow and ice, Anal. Chim. Acta, 156, 181-192, 1984.

Li, S.M., and L.A. Barrie, Brogenic sulfur aerosol in the Arctic troposphere, 1, Contributions to total sulfate, J. Geophys. Res., 98, 20,613-20,622, 1993.

McArdle, N.C., and P.S. Liss, Isotopes and atmospheric sulphur, Atmos. Environ., 29, 2553-2556, 1995.

McArdle, N.C., P.S. Liss, and P. Dennis, An isotopic study of atmospheric sulphur at three sites in Wales and at Mace Head, Eire, J. Geophys. Res., 103, 31,079-31,094, 1998.

Mossop, S.C., Volcanic dust collected at an altitude of $20 \mathrm{~km}$, Nature, 203, 824-827, 1964.

Newhall, C.G., and S. Self, The volcanic explosivity index (VEI): An estimate of explosive magnitude for historical volcanism, J. Geophys. Res., 87, 1231-1238, 1982.

Newman, L., H.R. Krouse, and V.A. Grinenko, Sulphur isotope variations in the atmosphere, in SCOPE 43, Stable Isotopes: Natural and Anthropogenic Sulphur in the Environment, edited by H.R Krouse and V.A. Grinenko, pp. 133-176, John Wiley, New York, 1991.

Nielsen, H., Isotopic composition of the major contributors to atmospheric sulfur, Tellus, 26, 213-221, 1974.

Nielsen, H., J. Pilot, L.N. Grinenko, V.A. Grınenko, A.Y Lein, J.W. Smith, and R.G. Pankina, Lithospheric sources of sulphur, in SCOPE 43, Stable Isotopes: Natural and Anthropogenic Sulphur in the Environment, edited by H.R. Krouse and V.A. Grinenko, pp. 65-132, John Wiley, New York, 1991.

Novak, M., S.H. Bottrell, D. Fottova, F. Buzek, H. Groscheova, and K. Zak, Sulfur isotope signals in forest soils of central Europe along an air pollution gradient, Environ. Sci. \& Technol., 30, 3473-3476, 1996.

Nriagu, J.O., R.D. Coker, and LA. Barrie, Origin of sulphur in Canadian Arctic haze from isotope measurements, Nature, 349, 142-145, 1991.

Rees, C.E., W.J. Jenkins, and J. Monster, The sulphur isotopic composition of ocean water sulphate, Geochim. Cosmochim. Acta, 42, 377-381, 1978.

Robinson, B.W., Sulphur and sulphate-oxygen isotopes in New Zealand geothermal systems and volcanic discharges, in Studies on Sulphur Isotope Variations in Nature, pp. 31-48, Int. At. Energy Agency, Vienna, 1987.

Robinson, B.W., Sulphur isotopes standards, in Reference and intercomparison materials for stable isotopes of light elements, $I A E A$ TECDOC-825, pp. 39-45, Int. At. Energy Agency, Vienna, 1995.

Saltzman, E.S., G.W. Brass, and D.A. Price, The mechanism of sulfate 
aerosol formation: Chemical and sulfur isotopic evidence, Geophys. Res. Lett., 10, 513-516, 1983.

Tanaka, N., D.M. Rye, Y. Xiao, and A.C. Lasaga, Use of stable isotope systematics for evaluating oxidation reaction pathways and in-cloud scavenging of sulfur dioxide in the atmosphere, Geophys. Res. Lett., 21, 1519-1522, 1994.

Wagnon, P., R.J. Delmas, and M. Legrand, Loss of volatile acid species from upper firn layers at Vostok, Antarctica, J. Geophys. Res., 104, 3423-3431, 1999.
R.J. Delmas, Laboratoire de Glaciologie et Géophysique de I'Environnement, CNRS, B.P. 96, 38402 St-Martin d'Hères, France. (delmas@glaciog.ujf-grenoble.fr)

J. Jouzel and N. Patris, Laboratoire des Sciences du Climat et de I'Environnement, UMR CEAVCNRS 1572, CEA Saclay, 91191 Gif-surYvette, France. (jouzel@lsce.saclay.cea.fr; npatris@lsce.saclay.cea.fr)

(Recieved February 11, 1999; revised September 7, 1999; accepted September 12, 1999.) 